\title{
WestVirginiaUniversity
}

THE RESEARCH REPOSITORY @ WVU

West Virginia Agricultural and Forestry Experiment

Davis College of Agriculture, Natural Resources

Station Bulletins

And Design

$1-1-1958$

\section{Transparent egg cartons vs. paper cartons}

Norman Nybroten

Follow this and additional works at: https://researchrepository.wvu.edu/ wv_agricultural_and_forestry_experiment_station_bulletins

\section{Digital Commons Citation}

Nybroten, Norman, "Transparent egg cartons vs. paper cartons" (1958). West Virginia Agricultural and Forestry Experiment Station Bulletins. 413.

https://researchrepository.wvu.edu/wv_agricultural_and_forestry_experiment_station_bulletins/395

This Bulletin is brought to you for free and open access by the Davis College of Agriculture, Natural Resources And Design at The Research Repository @ WVU. It has been accepted for inclusion in West Virginia Agricultural and Forestry Experiment Station Bulletins by an authorized administrator of The Research Repository @ WVU. For more information, please contact ian.harmon@mail.wvu.edu. 


\section{TRANSPARENT EGG CARTDNS}

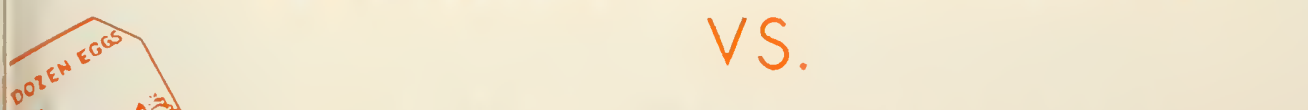

\section{PAPER CARTONS}

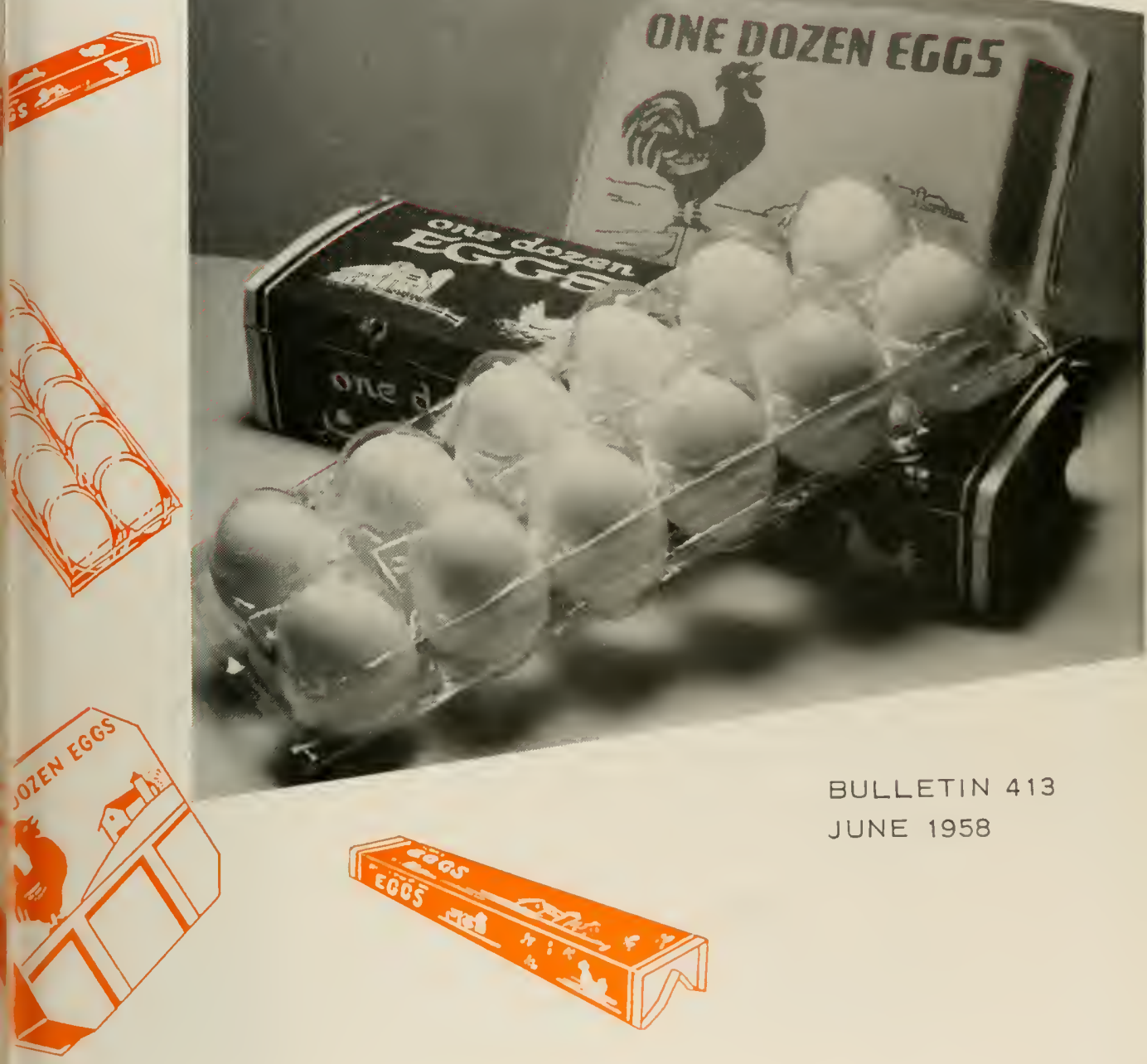




\section{THE AUTHOR}

Norman Nybroten, author of Transparent Egg Cartons as. Paper Cartons, was formerly Prolessor of Agricultural Economics at West Virginia University and Agricultural Economist in the West Virginia University Agricultural Experiment Station. He is now stationed at the Lniversity of Idaho, Moscow, Idaho.

West Virginia University

Agriglltekal. Explerimext Statiox

College of Agricletere, Forfatry, and Home Economics

1. H. Vanlaninghan, Acting Director

MORGANTOW' 


\section{Transparent Egg Cartons vs. Paper Cartons}

\section{Introduction}

NORMAN NYBROTEN

$l^{1}$

LRING recent years, plastic materials, often at increased cost, have become more common in packaging different food items. Logically, food merchandisers who have adopted a more expensive contaner must have done so under one or more of the following conditions: (a) there has been an offsetting gain in efficiency of handling the product; (b) the more expensive container gives better protection to the product; (c) the more expensive container attracts more volume and increases the demand for the product usually including the container; (d) the food merchandiser has no real choice in selecting the food container because other factors to be desised can not be separated from the expensive container; (e) the food merchandiser has analyed the economics of the situation in a mammer which gives him an incorrect conclusion or his choice may be based on noneconomic consideration.

The one-dozen plastic egg carton has been developed to a point where it might feasibly be comsidered as an alternative for paper egg cartons. In 1955, plans were made for testing consmmer acceptance of plastic egg cartons in W'est V'irginia, but suitable cartons were not available.

Tests have been made of consumer and shopper attitudes towarl these cartons in New York ${ }^{1}$ and . Iaine. ${ }^{2}$ ln matched-lot experinents eggs in plastic rs. eggs in paper cartons) in these states more cugs were old in plastic than in paper cartons. From these experiments it was ilso concluded that total egg sales, for the stores in which experinents iere conducted, were increased by the introduction of plastic (antons.

Matched-lot experiments are not designed to measure the eflect of a ubstitute imnovation on total sales. Methods other than matched-lot vere to have been used in the West Tirginia experiment after the matched-lot experiments were completed. Ihe results ol the diflerent. matched-lot experiments in West V'irginia, horrerel, were such that it lid not secm necessity to test by other methods.

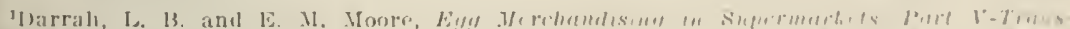

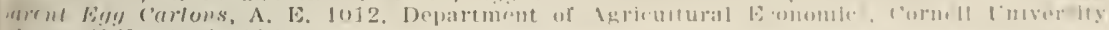
thata, $F$ Y., April 1954;

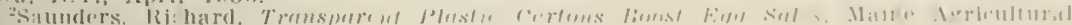

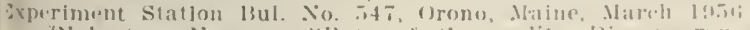

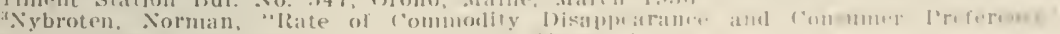

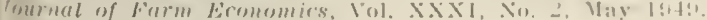




\section{The Study Method}

\section{EXI'ERIMENTS}

Three plases of matched-lot relationship were conducted in three stores in Parkersburg. Mest Virginia, over a 16 -week period. This tripli cation of stores was made so as to increase statistical validity. In two o the stores there were two classes of eggs (high-quality branded eggs alons with unclassified) and two types of patper cartons. The branded egg were not offered in the thind store. The quality and size of eggs and the type of carton were controlled during the experiment. The experimenta phases were in the following order.

Deposit phase. In this phase a deposit of 10 cents (on the plasti carton) was taken. A label was inserted into each egg carton, indicatin: price of the eggs, anomnt of deposit, and the total of the two.

Differential fhase. In this phase of the experiment attention wa called to the difference in costs of cartons, and the additional cost 0 the plastic carton was charged to the customer. In all stores 4 cent premium was charged lor the plastic carton over the $3 \mathrm{x} 4$ paper cartor In two stores, which had a higher-priced egg in a branded $2 \times 6$ cartor a premium of 3 cents was charged for the plastic over the $2 \times 6$ pape carton. In each case, these premiums were (to the nearest cent) th actual difference in cost of cartons. Slips rere inserted into the plasti cartons showing the price of eggs, the carton preminum, and the tota price. A banner over the display called attention to the fact that th same class or grade of eggs was packed each way, and that the carto was the only difference. The three types of cartons are those shown $i$ the picture on the cover page.

Same-price phase. In this phase cach class of eggs was available a the sanne price in either the plastic or paper carton. There was banner to show that there was no deposit nor premium charged fo eggs in plastic cartons. Customers had been alerted during the previou twelve weeks in which the deposit and price-differential phases had bee in operation. Again, real effort was made to convince customers tha there was 110 difference in the eggs offered in the two types of carton:

This phase was repeated in one store in Miorgantown, West Vir ginia, except lor two principal differences: (a) the customers had no becn alerted by prior experiments, and (b) there was no banner callin: attention to the fact that the two types of cartons contained eggs o the same class. Medium and large eggs, unclassified but controlled a to quality, were offered in this experiment. Equal display was given te each type of carton. 
PRICE

STORE TREATMENT

I

II

III

Deposit

Differential

Same Price

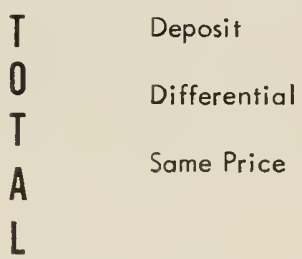

(shaded $=$ sales in plastic)

RESPONSE (unshaded $=$ sales in paper)

Percent of egg sales
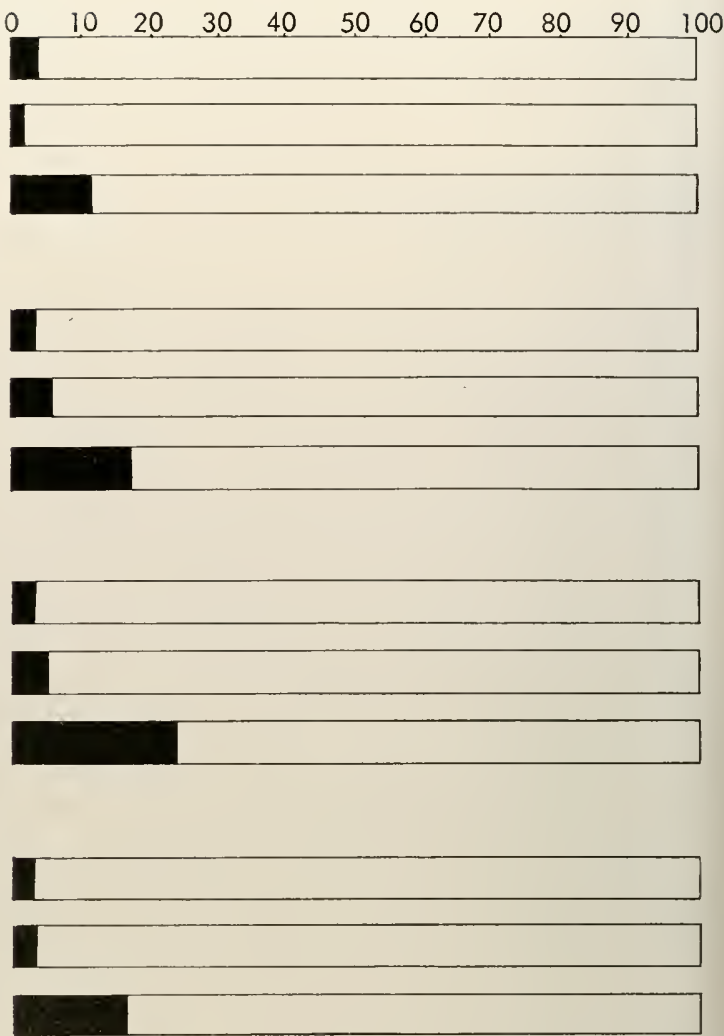

FIGURE 1. Relative sales of eggs in plastic vs. paper cartons in three supermarkets with three different price relationships between eggs in the two cartons.

nearer those obtained in Maine and New York. (Sec Table 1.) Even in this experiment, however, daily sales of eggs in plastic cartons were rather consistently smaller than sales in paper cartons. This same result held for both medium and large eggs and also for both $3 \times 4$ and $2 \times 6$ paper cartons. Not only were the sales of eggs in plastic cartons lower than sales in paper cartons-but there also was no time trend towarl accepting the plastic carton by the majority of the customers. 
Table 1. Results of a Matched-Lot Retall Experiment of Plastic vs. Paper Egg Cirtons, with yo Price Difference Between Cartons, Morgantowi, West Virginia, I957

\begin{tabular}{|c|c|c|c|}
\hline \multirow{2}{*}{$\begin{array}{c}\text { WEEK } \\
\text { (INDICATED BY } \\
\text { MONTH AND DAY) }\end{array}$} & \multicolumn{3}{|c|}{ Percentage of Eggs Sold iN Plastic Cartons } \\
\hline & MEDILN SIZE & LARGE SIZE & BотH SizES \\
\hline $10-2-10-5 \quad \ldots \ldots$. & 一 & 42.11 & 42.0 \\
\hline $10-7-10-12 \ldots$ & 一 & 44.11 & 44,11 \\
\hline $10-14-10-19$ & 54.0 & -.. & $54.0 *$ \\
\hline $10-21-10-26$ & 42.9 & $3+.1$ & 39.8 \\
\hline $10-28-11-2 \quad \ldots \ldots \ldots \ldots$ & 43.4 & 41.0 & 42.1 \\
\hline $11-4-11-9$ & 40.0 & 39.5 & 39.8 \\
\hline $11-11-11-16 \ldots$ & 40.6 & 30.4 & 36.1 \\
\hline $11-18-11-23$ & 40.5 & 36.7 & $3 \pi .5$ \\
\hline TOTAL & 43.8 & 39.2 & 41.2 \\
\hline
\end{tabular}

*This week the experiment was inadvertenly confounded. Large eggs appeared only in paper cartons for 2 days. If egg sizes were disregarled, 44.7 percent were sold in plastic and 55.3 per cent in paper. On the two days of this week during which types of carlons were completely matched-lot, 45.2 percent of the egge sold were in plastir 'arton: and 54.8 percent in paper cartons.

\section{SURVEY PHASE}

Results of the opinion surveys in West Virginia differed from the opinion surveys in the other two states less than the results of the Went Virginia experiments differed from the results of the experiments in those states. Homemakers interviewed in West Virginia expressed a fair amount of enthusiasm lor the plastic carton. (See Table 2.) In West Virginia 51 percent of the respondents expressed a preference for the plastic carton, compared with 71 percent in Maine and 62 percent in $\mathrm{New}$ York. In New York this preference might have been higher if the "plastic-top" carton had not becn presented as an alternative. It might be that the lower preference in Morgantown and Parkersburg indicates a decline in preference upon being better informed-experiments had been run in both of these cities. Various reasons were given for their meference or lack of preference. Their principal reason for choming he plastic carton was tsually that they liked to be able to see what in 1 the package.

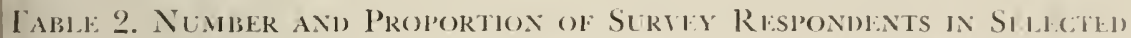
West Virganta Cimes Choosing Tripts of Egg Ciartons, 1957

\begin{tabular}{|c|c|c|c|c|c|c|c|c|c|c|}
\hline \multirow{2}{*}{$\begin{array}{c}\begin{array}{c}\text { TXPE } \\
\text { OF } \\
\text { CARTON }\end{array} \\
\text { 'Jastir. ........ }\end{array}$} & \multicolumn{2}{|c|}{ CHARLESTON } & \multicolumn{2}{|c|}{ CLARKSBLKR: } & \multicolumn{2}{|c|}{ MORGANTOWN } & \multicolumn{2}{|c|}{ PAKKKKSBL UR; } & \multicolumn{2}{|c|}{ Тити. } \\
\hline & $\begin{array}{l}\text { No. } \\
\text { Si }\end{array}$ & $\begin{array}{c}\% \\
5 \pi .1\end{array}$ & $\begin{array}{l}\text { No. } \\
72\end{array}$ & 5 & $\begin{array}{l}\text { No. } \\
111 .\end{array}$ & $\begin{array}{l}\% \\
10.5\end{array}$ & $\begin{array}{l}\text { No. } \\
12 ! !\end{array}$ & $\begin{array}{c}\% o \\
11 i .2\end{array}$ & No. & $\therefore$ \\
\hline$x$ f palper & 27 & $1 \$ .1$ & 11 & 10.9 & $: 32$ & 11.7 & 27 & $\because 7$ & 1141 & $1: "$ \\
\hline$x+$ paper & 14 & 9.4 & $2 s$ & 21.7 & is & Zfi,ti & $5 \%$ & 3.1 .1 & $19 \%$ & 252 \\
\hline ¿o difference & $2:$ & 15.1 & 15 & 11.1 & 211 & $\because .2$ & 24 & 10.11 & Sil: & 111 \\
\hline 11 Types & 149 & 1611.11 & 124 & $1(m+1.1)$ & 215 & $\mid 1111,1]$ & $27 ! 1$ & $|+1+1| \mid$, & $7 \div$ & 11,111 \\
\hline
\end{tabular}


The West Virginia opinion survey postulated that the plastic and the paper cartons were the same price. This postulation seemed rather unrealistic to many of the respondents, and their attiude indicates that in the same-price phase of the store experiments, customers might not believe they were getting the plastic carton for the same price as the paper carton, despite efforts to show there was no extra change. On the other hand-in experiments charging a premium for eggs packed in the plastic carton compared with eggs packed in paper cartons-the customer might have assigned the (lifference in price (and value) to difference in eggs rather than to difference in cartons. This conld account for the fact that Samders, ${ }^{5}$ in his Maine experiment, found as large a percentage of eggs sold in plastic at a 5 -cent premium for plastic as were sold at a 3-cent premium. Actually his study showed a slightly greater percentage of sales in plastic at a 5-cent premium than at a 3-cent premium-which might indicate that egg customers attributed the price difference to egg quality rather than to dilferences between plastic and paper cartons. However, the differences in the percentages of sales at the 5-cent and i-cent premiums were not statistically significant.

"Ibid. 